DOI: https://doi.org/10.24144/2409-6857.2019.2(54).29-40

УДК 35:330.341.1

Готра В.В., Щукін I.C.

\title{
СУТНІСТЬ ТА НАПРЯМКИ РЕФОРМУВАННЯ ДЕРЖАВНОЇ ІННОВАЦІЙНОЇ ПОЛІТИКИ В УМОВАХ ЄВРОІНТЕГРАЦІї
}

\begin{abstract}
У статті досліджено значення та сучасні напрямки державної інновачійної політики. Проаналізовані теоретичні аспекти необхідності реструктуризації у сфері економіки та законодавчої бази для успішної реалізації євроінтеграційних процесів держави. Внесено пропозиції для коректив державної інноваційної політики країни враховуючи сучасну геополітичну та економічну ситауцію.
\end{abstract}

Ключові слова: державна інновачійна політика, прочес євроінтеграції, науково-технічний розвиток, інновачіï, функиії та напрямки ДІП.

Постановка проблеми. Україна пройшла ряд соціально-економічних перетворень, на яких базується ринкова економіка, а також був накопичений необхідний потенціал економічного зростання, що має вивести Україну на траєкторію сталого розвитку. Обраний Україною шлях інтеграції до Європейського Союзу та світового співтовариства через широке міжнародне співробітництво призводять до усвідомленої необхідності виробити концептуальні підходи до розвитку національної економічної системи 3 урахуванням теоретико-методологічних обгрунтувань та світового досвіду досягнень передовими країнами сталого розвитку. Одним 3 таких підходів $\epsilon$ розробка та впровадження сучасної державної інноваційної політики (ДІП) для досягнення успішного економічного результату в умовах євроінтеграції. В результаті чого забезпечується підвищення конкурентоспроможності по світовим макро- та мікроекономічним показникам держави. Аналіз останніх досліджень і публікацій. Дослідженню інноваційної політики держави присвячені праці багатьох вітчизняних та зарубіжних вчених: Гусєв В.О., Н.В. Красноутська, О.В. Бондар, Л. Водачек, Л.Б. Міротін, I.І. Мазур та інші. Все ж багато питань залишається не вирішеними, потребує подальшого дослідження та удосконалення механізму державного регулювання у інноваційній сфері, законодавче стимулювання та управління інноваційною діяльністю для забезпечення зростання економіки України.

Формулювання цілей статті. Завданням даної статті є дослідження основних аспектів

(C) Готра В.В., д.е.н., доц., професор кафедри економіки та підприємництва ДВНЗ «Ужгородський національний університет», м. Ужгород, email:viktoriya.hotra@ uzhnu.edu.ua

Щукін І. С., аспірант ДВНЗ «Ужгородський національний університет», м. Ужгород. інноваційної політики України та їх сутність. Визначення існуючих проблем у іï функціонуванні та можливих шляхів їх подолання.

Опис основного матеріалу дослідження. Під інноваційною політикою слід розуміти комплекс принципів та взаємопідтримуючих економічних, правових, організаційних і соціальних методів планування, стимулювання, регулювання та контролю процесів інноваційної діяльності в науково-технічній та виробничій сферах.

Метою інноваційної політики провідних країн світу $\epsilon$ сприяння розвитку науки й техніки, підвищення інноваційної активності, що забезпечує конкурентоспроможність національної продукції на світовому ринку, підримку належного рівня обороноздатності країни, покращення екологічної ситуації, а також сприяє розвитку венчурного довгострокового бізнесу. Виходячи з цієї мети, держава визначає пріоритетні напрями розвитку інноваційної діяльності та обирає основні шляхи підтримки підприємств, які працюють над виконанням державних інноваційних програм. Пріоритетні напрями - це тематичні сфери науки і техніки, які мають першочергове значення для досягнення перспективних i поточних цілей соціальноекономічного розвитку. Вони формуються під впливом національно-економічних, політичних, екологічних та інших чинників. Залежно від масштабу вирізняються глобальні (загальносвітові), міжнародні (система країн) i національні (окремі країни) пріоритети розвитку науки й техніки [10].

Для більш чіткого розуміння терміну інноваційна політика пропоную визначення від науковця Бондар О.В., який вказує, що державна інноваційна політика - це комплекс заходів щодо розвитку національної інноваційної системи; інструмент реалізації інноваційної моделі розвитку економіки та сталого розвитку країни, а 
також складова частина загальної політики держави, яка має систематично порівнюватися 3 інноваційною політикою технологічно розвинених країн, створюючи національне мистецтво управління інноваціями. Отже, саме державна інноваційна політика має стати інструментом забезпечення сталого розвитку України, тобто збалансованого розвитку економічної, соціальної та екологічної складової суспільного устрою, процесу змін, в якому експлуатація природних ресурсів, напрямок інвестицій, орієнтація науково-технічного розвитку, розвиток особистості та інституційні зміни погоджені один 3 одним і зміцнюють нинішній і майбутній потенціал для задоволення людських потреб і прагнень [2]. Також важливо додати, що для ряду пострадянських країн, це свого роду національне дозрівання та усвідомлення необхідності всестороннього розвитку держави шляхом впровадження інновацій. Внаслідок чого виникає можливість надолужити втрачений час та позиції держави по міжнародним показникам та зміцнити свої можливості протистояти несприятливим різким змінам у світовій економіці.

Утвердження інноваційної моделі розвитку національної економіки здійснюється через поширення інноваційних процесів в усіх іiі галузях та спричинені цими процесами прогресивні зміни у сфері виробництва, зокрема, його технологічній структурі, а також в якісних змінах сфери споживання. Державна інноваційна політика виступає засобом підтримки генерації, розвитку та поширення інноваційних процесів, при цьому перевага має надаватися інноваційним процесам, за якими здійснюється технологічне переозброєння виробництв на базі високих технологій, утвердження вищих технологічних укладів (п'ятого та шостого).

Об’єктами державної інноваційної політики виступають інноваційні процеси, пріоритетні напрями яких встановлені законодавством, i відповідні сегменти їх перебігу у сфері інноваційної діяльності.

Суб'єктами державної інноваційної політики стають відповідно усі учасники інноваційних процесів на будь якій їх фазі, якщо вони є провідниками державної інноваційної політики, зокрема, органи державної влади, що здійснюють підтримку їх генерації, розвитку та поширення в усіх галузях національної економіки.

Державна інноваційна політика (синонімічні поняття: державна політика у сфері інноваційної діяльності, державна інноваційна політика — далі ДІП) - це стрижнева складова державної політики, як організуюча, регулятивна та спрямовуюча інституціональна субстанція суспільства щодо утвердження сталого інноваційного розвитку національної економіки для забезпечення іiі конкурентоспроможності та прогресивних структурних змін i $\epsilon$ цілеспрямованою та скоординованою діяльністю органів державної влади загальнодержавного, галузевого, регіонального рівнів для впровадження комплексу організаційних, регуляторних, управлінських заходів на основі певних принципів та розроблених стратегій i спрямованих на створення системних інституціональних, економічних, науковотехнічних та інших засад, а також запровадження механізмів їх реалізації через залучення необхідних інвестиційних, інтелектуальних, інформацій" них, матеріально-технічних, організаційних та інших ресурсів (державних та недержавних) для стимулювання генезису та широкомасштабного поширення інноваційних процесів на всіх рівнях та в галузях національної економіки, але 3 переважною їх державною підтримкою за встановленими законодавством пріоритетними напрямами [3, 4].

ДІП, що спрямована на підтримку генезису та поширення інноваційних процесів на всіх фазах їх розвитку i перебігу в інституціональному просторі, відповідно має поєднати економіку, науку, техніку, підприємництво, ринок споживання інноваційної продукції. Таким чином, предметним середовищем запровадження ДІП $\epsilon$ соціально-економічне середовище, включаючи науково-технічну, виробничу, фінансову сфери, а також сферу державного управління.

Важливо відзначити комплексний характер заходів ДІП, їх системний взаємозв'язок 3 механізмами реалізації та ресурсним забезпеченням, а також інституціональну спроможність органів державної влади стосовно впровадження ДІП. Разом це складає імперативи впровадження ефективної ДІП.

Багаторічна практика утвердження інноваційної моделі розвитку економіки України доводить, що окремі безсистемні заходи інституціонально неспроможних органів державної влади стосовно стимулювання інноваційної діяльності, а також без відповідного ix ресурсного забезпечення $\epsilon$ мало результативними i найчастіше надають ефект, протилежний очікуваному.

Сукупність мети, цілей, принципів, пріоритетів та стратегій запровадження ДІП визначають іiі формат, що визначається реаліями та цілями трансформаційного перехідного етапу національної економіки, станом іiі науково- 
технологічного, кадрового, виробничого потенціалів, іï технологічною структурою, а також імперативами досягнення сталого розвитку країни 3 випереджаючими темпами відносно темпів розвитку провідних країн світу.

Сформульоване визначення ДІП окреслює контур іï змістовного наповнення, тобто що має бути розкрито в процесі її вироблення і водночас доводить - державна інноваційна політика має право називатися такою завдяки особливостям змістового наповнення іiї формату, відмінному від інших політик.

Існують тісні системні взаємозв'язки ДІП з економічною, інвестиційною, інституціональною, науково-технічною, освітньою, промисловою, структурною політикою держави, а також 3 економічними дисциплінами, насамперед 3 інноваційною економікою чи економікою технологічних змін. Разом 3 тим активна державна інноваційна політика має певну самостійність і здійснює визначальний вплив на зазначені політики та національну економіку, формуючи їх інноваційну спрямованість. Більше того, за умов утвердження інноваційної моделі розвитку національної економіки інноваційну політику можна розглядати як стрижневу основу зазначених політик та національної економіки.

Подібні тісні взаємозв'язки та взаємозалежності спонукають до визначення цілей, пріоритетів та специфічних механізмів формування та реалізації державної інноваційної політики у предметних сферах інвестиційної, інституціональної, науково-технічної, освітньої, промислової (чи більш узагальнено галузевої), структурної політик, що можна трактувати як спільні цілі, пріоритети та інше або як такі, що досягаються проведенням державної інноваційної політики у відповідних предметних сферах цих політик. При цьому за теперішніх умов, відсутність науково обгрунтованої та ефективної державної інноваційної політики негативно впливає на темпи інноваційного розвитку національної економіки, що визначено стратегічним пріоритетом державної політики, гальмуючи його, та не дозволяе досягнути необхідного рівня ії конкурентоспроможності для включення України в систему міжнародних економічних відносин як повноправного їх учасника.

Виокремлення ДІП у загальній державній політиці як відносно самостійної іiї стрижневої компоненти зумовлено специфікою інноваційної сфери діяльності та врегулювання відносин, що існують у цій сфері, а також значущості інноваційної політики для досягнення випереджаючих темпів розвитку національної економіки на якісно новому технологічному рівні.

Для визначення місця ДІП у системі суспільних відносин маємо виходити 3 таких суттєвих положень аксіоматичного характеру, а саме:

- ДІП входить у сферу політичних відносин, тому що вона являє собою відносини, які виникають у зв'язку з діяльністю держави, іiі органів влади у сфері інноваційної діяльності і галузях, які ця сфера охоплює, та інституціонального середовища підтримки інноваційної діяльності;

- ДІП має характерні властивості, що випливають із: специфіки інноваційної сфери діяльності; правовідносин, що виникають між суб'єктами інноваційних процесів; закономірностей економічного розвитку та законів, які управляють виробництвом, розподілом та споживанням інноваційної продукції;

- ДІП базується на економіці технологічних змін (зараз вживається ще назва інноваційна економіка) і в певній мірі $є$ іiі концентрованим виразом та завершенням.

ДІП має багатофункціональне призначення, що полягає, зокрема:

за господарською функцією - у введенні у господарський обіг об'єктів прав інтелектуальної власності, створених у науково-технічній сфері діяльності 3 метою їх комерціалізації або отримання соціально-економічного ефекту;

за гуманітарною функцією - у сприянні розвиткові творчого потенціалу людини, як головного суб'єкта інноваційних процесів та їх ініціатора;

за економічною функцією - у забезпеченні економічного розвитку та конкурентоспроможності підприємств, галузей, регіонів, національної економіки на базі інноваційної модернізації чи реструктуризації сфер науково-технологічної, освітньої та виробничої діяльності;

за пізнавальною функцією - у сприянні продукуванню нових знань прикладного характеру та розробленню передових технологій;

за соціальною функцією - у забезпеченні продукування суспільно корисних благ нової якості.

ДІП повинна бути функціонально пов'язаною iз стратегічними цілями соціально-економічного розвитку, а не тільки вирішувати поточні проблеми.

Орієнтація ДІП на соціально-економічний розвиток передбачає створення певних передумов ii запровадження, зокрема досягнення в 
суспільстві загальноекономічної та соціальної стабільності.

Для інноваційного типу економічного розвитку характерним $\epsilon$ системний комплекс інституціонального, ресурсного та інформаційного забезпечення, що разом 3 мотиваційними чинниками у суб'єктів інноваційного процесу відіграють роль визначальних факторів інноваційного розвитку, а також $\epsilon$ його загальними характеристиками. Комплекс цих факторів, взаємопов'язаний з ДІП, має сприяти іiі ефективному запровадженню.

ДІП неминуче повинна мати тісну взаємозалежність та взаємозв'язок 3 іншими політиками, зокрема 3:

— інвестиційною політикою в частині іiі спрямування за інноваційним вектором, а також забезпечення реалізації ДІП інвестиційними ресурсами;

інституціональною за напрямом інституціонального забезпечення реалізації ДІП;

- науковою та науково-технічною політикою за напрямами інтенсифікації прикладних досліджень, результати яких мають перспективи комерціалізації, будучи введеними в інноваційний процес, а також введенням об'єктів прав інтелектуальної власності, створених у науковотехнічній сфері діяльності, у господарський обіг через інноваційні процеси;

- промисловою політикою за напрямами широкомасштабного запровадження технологічних та продукційних інновацій відповідно для технічного переоснащення виробництв на новітній технологічній базі, модернізації або заміни основних виробничих фондів, освоєння випуску інноваційної продукції, підвищення

конкурентоспроможності промислових виробництв за інноваційним вектором їх розвитку;

- структурною політикою за напрямом реалізації прогресивних змін у технологічній структурі національної економіки, оптимізації галузевої структури національної економіки шляхом утвердження ефективних організаційноправових форм господарювання, що інституціонально спроможні до ефективної генерації та розвитку інноваційних процесів. Зв'язок ДІП із зазначеними політиками зумовлений спільністю цілей та використанням однакових механізмів упровадження. Цей зв'язок за певними проблемами доцільно виражати через інтегровану категорію _ «інноваційна реструктуризація».

Доцільність введення в категоріальнопонятійний апарат державної інноваційної політики терміна «інноваційна реструктуризація», що предметною сферою свого застосування може мати національну економіку або іiі окрему галузь, сектор чи інституціональну одиницю, розкривається за таким дискурсом.

Реструктуризація як термін не має усталеного визначення. Часто за своїми ознаками процес реструктуризації трактується як комплексні зміни структури активів та пасивів підприємства, а також системи управління 3 метою досягнення ефективності та конкурентоспроможності підприємства. Ряд науковців та управлінців практиків вбачають у реструктуризації підприємства виокремлення у його складі життєздатних господарських структурних одиниць, що спроможні до самостійного господарювання та розвитку. Під реструктуризацією також розуміють прогресивні зміни технологічної, виробничої структури, логістичної схеми забезпечення діяльності підприємства. В поняття реструктуризації також включають перетворення відносин власності та організаційно-правових форм функціонування підприємства, наприклад, корпоратизацію підприємства. Близькими поняттями до реструктуризації $\epsilon$ реформування та реорганізація, хоча остання найчастіше асоціюється із зміною організаційно-правових форм функціонування підприємства та має розглядатися як складова реструктуризації.

Вчений Мазура I.I. [12, с. 20] описує, що реструктуризація розкривається як сукупність заходів щодо комплексного приведення умов функціонування компанії у відповідність до змінених умов ринку і розробленої стратегією їі розвитку. Реструктуризація має включати: удосконалення структури та функцій управління, подолання відставання в техніко-технологічних аспектах діяльності, удосконалення фінансовоекономічної політики і досягнення на цій основі підвищення ефективності виробництва, конкурентоспроможності продукції, послуг, зростання продуктивності праці, зниження витрат виробництва та поліпшення фінансовоекономічних результатів діяльності [12, с. 20].

Термін реструктуризація стосовно підприємств достатньо повно розкрив Л. Водачек [1]. Реструктуризацію даний автор визначає як комплексні та взаємопов'язані зміни структури системи, що забезпечують більш ефективне функціонування підприємства у цілому. В організаційному плані об'єктом реструктуризації є суб'єкт господарської діяльності. Реструктуризація передбачає зміни виробничої програми та пов'язані із цим інноваційні зміни в таких структурах: виробничій (складових виробничо-технологічної бази); функціональній 
(при реалізації функції суспільного розподілу праці); інформаційній (інформаційні системи); організаційній (економіко-правові форми, зміни розподілу прав та обов'язків на підприємстві); кадровій (професіональний та кваліфікаційний склад працівників); фінансовій (активи та пасиви).

Узагальнюючи, визначаємо, що реструктуризація $\epsilon$ складною категорією менеджменту, метою запровадження якої $\epsilon$ оптимізація бізнес-процесів, виробничих, організаційних, а також забезпечувальних їх процесів, застосування гнучких систем управління. Словосполучення «інноваційна реструктуризація» - це не формальне поєднання ад'єктива «інноваційна» 3 іменником «реструктуризація». Ад’єктив «інноваційна» як похідна від інновації включає ознаки цієї базової соціально-економічної категорії інноваційної економіки і переносить їх на «реструктуризацію», внаслідок чого вона набуває у цьому словосполученні більш складного змістовного наповнення, ніж просто зміни організаційної структури чи зміни фінансово-економічних умов діяльності об'єкта реструктуризації. Це складне змістовне наповнення, яке включає шість складових: застосування нової технології виробництва; запровадження нової продукції, товару, послуги; впровадження нової організації якогось виробничого, управлінського процесу, організаційної структури або їх удосконалення; використання нових енергетичних ресурсів, матеріалів, видів сировини, а також джерел їх постачання; відкриття та засвоєння нового ринку споживання продукції; підрив монополії конкурентів або створення монопольних умов для виробництва новітньої власної продукції.

3 наведених шести традиційних складових інновації, упорядкованих за ступенем їх визначального впливу, перші чотири складові можуть бути визначені як ендогенні інноваційні фактори, тобто пов'язані 3 організацією внутрішніх виробничих процесів і які мають бути використані у процесах реструктуризації. Зазначені ендогенні фактори інновації безпосередньо здійснюють вплив на бізнеспроцеси та виробничі процеси організації у цілому, а також визначають позиції та поведінку організації на ринку (5-та та 6-та складові). Серед перелічених складових категорії інновації визначальне значення має застосування нової технології (технологічні або процес інновації), що має привести не тільки до технологічних змін виробництва, але й до змін інших його характеристик.
Центральним активним суб'єктом процесів інноваційної реструктуризації $є$ людина. Роль людського фактора як сукупності духовних, інтелектуальних, соціальних, фізичних якостей та можливостей людей, що проявляється в процесі суспільного виду діяльності, значно зростає. Звідси інноваційна реструктуризація має передбачати прогресивні зміни людського фактора, зокрема через підготовку, перепідготовку, підвищення кваліфікації персоналу.

При інноваційній реструктуризації відбувається перехід до іншого стану діяльності об'єктів та суб'єктів інноваційної реструктуризації, рівня їх організації та якості діяльності, що $є$ аргументацією для характеристики інноваційної реструктуризації як фактора активізації інноваційних змін, детермінованих переважно інституціональними, структурними, технологічними чинниками. Крім зазначених функцій, інноваційна реструктуризація виконує також відтворювальну та інвестиційну функції або стимулює їх реалізацію.

У цьому контексті інноваційну реструктуризацію можна охарактеризувати як систему заходів, що ініціюють переведення виробництва до нового стану, який відповідає об'єктивним потребам його інноваційного та соціально-економічного розвитку.

Інноваційна реструктуризація національної економіки розкривається як запровадження комплексу організаційних, інституціональних, науково-технічних, економічних заходів, що мають забезпечити прогресивні структурні та інституціональні зрушення в технологічній, міжгалузевій, галузевій та регіональній структурі економіки у напрямку іï переходу на передову технологічну базу, зростання питомої ваги наукомісткої конкурентоспроможної інноваційної продукції, інтелектуальних послуг, а також забезпечити відповідні зміни структури внутрішнього ринку та експортної продукції, що в кінцевому результаті має посилити конкурентоспроможність національної економіки у світі. Наслідками проведеної інноваційної реструктуризації має стати перехід галузей, окремих виробництв до нового якісного стану, що відповідає об'єктивним потребам соціальноекономічного розвитку $[5,6]$.

Безумовно, неможливо досягнути синхронізації усіх процесів трансформації суспільних, господарських відносин та інноваційних технологічних змін внаслідок різної сили дії інституціональних та ресурсних обмежень, як гальмуючих чинників перебігу цих 
процесів, але вони мають розвиватися принаймні коеволюційно. Це передбачає взаємозумовлені, узгоджені зміни як технологічної структури економіки, так і в системі суспільно-економічної діяльності в процесі їх розвитку.

Змістовне наповнення ДІП включає комплекс цілеспрямованих економічних, політичних та організаційних заходів на різних рівнях національної економічної системи, скерованих на компенсацію недоліків та посилення дії ринкових механізмів; розвиток інноваційної інфраструктури підтримки генезису інноваційних процесів; компенсацію негативних екологічних впливів; удосконалювання галузевої структури виробництва; регулювання і стимулювання інноваційно-інвестиційної діяльності; формування вертикально та горизонтально інтегрально-інтегрованих структур (промисловофінансові групи, територіальні кластери, а також інші мережеві структури); заохочення малого та середнього бізнесу до інноваційної діяльності та інше.

Формат ДIП має загальнодержавний (макрорівень), галузевий (мезорівень), регіональний (мезорівень), міждержавний (мегарівень) виміри свого формування та запровадження. Ці виміри ДІП згідно з діалектикою переходу кількості в якість визначають особливості системи цілей, стратегій, інституціонального середовища та механізмів запровадження, що не зводяться до механістичних змін їх масштабів, а навпаки, ці системні складові ДІП набувають нового якісного змісту в іншому вимірі, що дозволяе характеризувати ДІП відповідно як загальнодержавну, галузеву, регіональну та міжнародну інноваційну політику або розглядати ДІП за цими аспектами. На мікрорівні ДІП знаходяться підприємства, організації, установи, що $є$ безпосередніми учасниками інноваційних процесів, на стимулювання та підтримку яких спрямована ДІП.

Результатом запровадження ДІП на мікрорівні має стати підвищення конкурентоздатності підприємств, на мезорівні - регіонів та галузей національної економіки, а на макрорівні національної економіки.

Принципи державної інноваційної політики є важливою складовою процесів іiі формування i реалізації. За визначеною системою принципів ДІП розробляється, а у подальшому треба дотримуватися цих принципів при іï впровадженні. Принципи визначають вимоги до формату, структури ДІП, а також до механізмів та процесів державного управління щодо ii запровадження. Принцип (від лат. principium - основа, начало) як базове поняття, основа системи являє собою узагальнення, розповсюдження якого передбачається на всі частини системи або явища тієї галузі, 3 якої принцип був абстрагований. Принцип часто виступає як аксіоматичне теоретичне знання, що не потребує доведень і розуміється як найбільш основне початкове положення теорії чи загальне правило діяльності, що забезпечує правильність, але не гарантує ще його успішну реалізацію. Принципи також являють собою результат узагальнення об'єктивних законів та закономірностей, характерних рис, фактів, що стають основою для цілепокладання, планування та здійснення певної діяльності.

ДІП розробляється та реалізується відповідно до принципів: - включення ДІП як стрижневої складової до державної соціально-економічної політики, програми діяльності Уряду, а також іiі органічного поєднання 3 амортизаційною, інвестиційною, науково-технічною, податковою, промисловою, структурною політикою та іншими політиками при входженні їх до відповідних сегментів регулювання сфери інноваційної діяльності;

- випереджаючого інноваційного розвитку, що передбачає забезпечення темпів зростання валового внутрішнього продукту на душу населення за рахунок сталого інноваційного розвитку вище, ніж у розвинених країнах світу 3 метою досягнення показників економічного розвитку, які мають відповідати критеріям вступу країн до Євросоюзу;

- відкритості та прозорості ДІП для суспільства, зокрема, забезпечення постійного моніторингу та оцінювання ефективності проведення державної інноваційної політики, а також забезпечення конкурсного відбору інноваційних проектів при їх фінансуванні державними коштами або виконанні за державним замовленням;

- інтеграції наукової, науково-технічної, виробничої та освітньої діяльностей;

- наукової обгрунтованості визначення пріоритетів та вибору стратегій інноваційного розвитку на основі наукового передбачення (foresight) основних напрямків освоєння науковотехнологічних досягнень у світовому виробництві та в Україні у короткостроковій, середньостроковій та довгостроковій перспективах;

- необхідного інституціонального, а також достатнього інвестиційного, фінансового та іншого ресурсного забезпечення за програмноцільовими та проблемно-орієнтованими підходами, при цьому це ресурсне забезпечення 
має бути зорієнтованим переважно на внутрішні джерела;

- посилення ролі держави та поєднання державної регуляції з ринковими механізмами саморегуляції у сфері інноваційної діяльності, при цьому державне управління має бути адекватним ринковим відносинам, а державна підтримка інноваційних процесів має бути причиною первинного поштовху та бути спрямованою на створення механізмів розширеного самовідтворення;

- рівноправного партнерства держави із суб'єктами інноваційної діяльності недержавної форми власності 3 метою об'єднання зусиль, ресурсів держави і підприємницького сектора економіки, що передбачає налагодження державно-приватного (публічно-приватного) партнерства для розвитку інноваційної діяльності;

- розвитку міжнародного співробітництва у сфері інноваційної діяльності з метою приєднання або включення до передових світових технологічних «ланцюгів» і входження у світовий технологічний простір;

соціально-економічної спрямованості інноваційних перетворень, тому на всіх етапах формування й реалізації ДІП необхідно виходити 3 пріоритету інтересів широких верств населення щодо підвищення їх добробуту, збереження та збільшення робочих місць, забезпечення екологічної безпеки та рівноваги;

- урахування національних інтересів у сфері інноваційної діяльності, що має різноманітні прояви: захист прав на інтелектуальну власність при іiі введенні у господарський обіг у ході реалізації інноваційних процесів, позбавлення залежності від «критичних технологій» та «критичного імпорту», збереження та примноження національного інтелектуального потенціалу, протекціонізм вітчизняним виробникам наукомісткої продукції та надання їм допомоги щодо просування цієї продукції на внутрішній та зовнішній ринки тощо;

- визнання збереження та зміцнення науковотехнологічного потенціалу, утвердження інноваційної моделі розвитку пріоритетом національних інтересів [12];

- формування ДІП відповідно до парадигми сталого інноваційного розвитку, що складає іiі аксіологічний та гносеологічний базис.

Додержання системи цих принципів у процедурах розроблення та впровадження ДІП має забезпечити іiі результативність та ефективність.

Мета та система цілей державної інноваційної політики. Для цілепокладання ДІП мають бути оптимізовані й збалансовані у просторовому та у часовому вимірах водночас цілепокладання на макро-, мезо- та мікрорівнях за умов урахування їх взаємовпливів. Це передбачає деталізацію цілей державної підтримки інноваційної діяльності у масштабі від макрорівня (національна економіка) до мезорівня (галузь, регіон) i так до прогнозування сприйняття державної інноваційної політики окремим підприємством. При цьому формування цілей макрорівня передбачає врахування невирішених проблем інноваційного розвитку на мікрорівні. Для раціоналізації формування ДІП мають бути використані загальносистемні критерії оптимізації [11]:

- між цілями ДІП та ресурсами, що можуть бути мобілізовані для їх досягнення;

- між часом, що відводиться для досягнення намічених цілей та синхронізацією видатків виділених ресурсів;

- між вартістю кожного цільового результату, досягнутого в процесі видатків ресурсів та ефективністю їх використання (споживання) в процесі інноваційного розвитку, а також 3 урахуванням ризиків недосягнення раніше запланованих цільових параметрів.

У довгостроковому періоді метою ДІП $\epsilon$ досягнення сталого інноваційного розвитку національної економіки на передовій технологічній базі, утвердження інноваційної моделі розвитку України, інтенсифікації та постійного розширеного відтворення інноваційних процесів в усіх галузях економіки, утворення елементів та ключових факторів вищих технологічних укладів, інтеграція до єдиного Європейського наукового та інноваційного простору, приєднання (або включення) до світових передових технологічних ланцюгів. Все це разом має забезпечити в цілому конкурентоспроможність національної економіки на внутрішньому та зовнішньому ринках, утвердження України у світовій спільноті як високотехнологічної держави.

3 визначеної мети ДІП зрозуміло іiї пріоритетність як засобу реалізації економічних реформ, адже ціллю структурного реформування економіки України $є$ наближення іï існуючої розвиненої, але неефективної технологічної структури до певного оптимуму, характерного для постіндустріального суспільства в умовах соціально орієнтованої ринкової економіки.

Для досягнення цієї мети державної політики розбудови інноваційно орієнтованої економіки України, за існуючих передумов розвитку інноваційних процесів в економіці, домінування нижчих технологічних укладів, мають бути 
вирішені такі наступні основні системні завдання, що співвідносяться з багатовимірною системою цілей інноваційної політики. Ця система цілей підпорядкована меті державної інноваційної політики та може бути структурована за багатовимірними сферами впливу цієї політики $[7,8]$.

У сфері інституціональної політики та державного управління ціллю ДІП, відповідно до інституціонально-системного підходу і за передовою світовою практикою, а також засобом упровадження ДІП, виступає розбудова інституціонального середовища, сприяння генерації та розвитку інноваційних процесів, що відповідає розбудові національної інноваційної системи і включає реалізацію наступних завдань:

- створення оптимальної цілісної системи державних органів, організацій, підприємств при забезпеченні структурної повноти їх повноважень у сфері інноваційної діяльності. На цю систему мають покладатися функціональні завдання реалізації ефективної державної інноваційної політики та іiі ресурсного забезпечення;

- прийняття відповідної законодавчої та нормативно-правової бази сприяння генерації та поширенню інноваційним процесам в економіці та розвитку системи інститутів підтримки інноваційної діяльності;

- формування на загальнодержавному, галузевих, регіональних рівнях науково та економічно обгрунтованих пріоритетів і стратегій інноваційного розвитку реального сектора економіки, що мають визначальний вплив на підвищення ефективності виробництв та конкурентоздатності продукції, утворення елементів вищих технологічних укладів;

- впровадження фінансово-економічних, організаційних та мотиваційних механізмів, що мають сприяти розвиткові та поширенню інноваційних процесів в економіці, зокрема, запровадження дійових механізмів введення в господарський обіг об’єктів інтелектуальної власності, трансферу технологій, нагромадження капіталу та його освоєння на інноваційні перетворення виробництв (інноваційна реструктуризація);

- запровадження програмно-цільових та проблемно орієнтованих методів управління інноваційними процесами та їх ресурсним забезпеченням, базовим елементом та об'єктом таких методів управління мають стати розроблені відповідно до визначених інноваційних пріоритетів інноваційно-інвестиційні проекти i програми;

формування державної системи передбачення (foresight), прогнозування й верифікації напрямів науково-технологічного та інноваційного розвитку;

- утворення державної системи проведення комплексної експертизи та фінансовоекономічного аналізу інноваційно-інвестиційних програм та проектів;

- організація моніторингу та оцінювання державної інноваційної політики на основі розробленої повної та релевантної статистичної звітності 3 питань інноваційної діяльності, відповідної до стандартів країн Євросоюзу;

- створення умов для розвитку фінансовокредитних інститутів банківського та небанківського секторів, а саме: спеціалізованих банків інноваційного розвитку та реконструкції, інноваційних фондів на загальнодержавному, регіональному та галузевому рівнях, венчурних фондів, спеціалізованих інноваційних лізингових фондів та компаній тощо, що надають фінансові послуги у сфері інноваційної діяльності;

- сприяння розвиткові інфраструктури підтримки та супроводження інноваційних процесів, що включає: технологічні та індустріальні парки, інноваційні центри, бізнесінкубатори та інші інноваційні структури, консалтингові та інжинірингові підприємства, центри експертизи тощо, а також сприяння діяльності громадських об'єднань та організацій у сфері інноваційної діяльності й налагодження 3 цими організаціями взаємодії державних інститутів у сфері інноваційної діяльності;

- формування й підтримка необхідних інформаційних банків даних у сфері інноваційної діяльності, створення та організація ефективної системи доступу суб'єктів інноваційних процесів до цих розподілених інформаційних ресурсів через побудовану державну інтегровану корпоративну інформаційну мережу;

- проведення виваженої тарифної політики формування та захисту внутрішнього ринку наукомісткої продукції, зокрема, в галузях зв 'язку та телекомунікацій, машинобудівної, радіоелектронної, фармацевтичної, а також продукції складної побутової техніки, програмних продуктів тощо;

— забезпечення тісної інтеграції освіти, науки, виробництва, підприємництва 3 метою сприяння розвиткові інноваційних процесів, зокрема, розробити та впровадити дійові схеми вертикальної та горизонтальної інтеграції підприємств, наукових установ та фінансовокредитних установ для організації випуску високотехнологічної та наукомісткої продукції.

У соціально-економічній, освітній та науковотехнічній сферах ці завдання будуть полягати в наступному:

— органічне включення інноваційних фак- 
торів до соціально-економічного розвитку країни;

- удосконалення на основі проблемно орієнтованого підходу організаційнофункціональної структури науково-технічного потенціалу за напрямами: оптимізації мережі державних науково-дослідних установ, створення нових проблемно орієнтованих прогресивних організаційних науково-виробничих та інноваційних структур, зокрема інжинірингових центрів, розширення недержавного сектора науково-технічної та інноваційної діяльності;

- забезпечення за науково прогнозованими та економічно обгрунтованими напрямами науковотехнічного прогресу випереджаючого розвитку науково-технічної сфери та системи вищої освіти, як витоків, відповідно, інноваційних процесів та підготовлених спеціалістів-учасників цих процесів;

- формування наукових заділів та підтримка цільових досліджень за державним замовленням на науково-технічну та інноваційну продукцію відповідно до встановлених законодавством пріоритетних напрямів розвитку науки і техніки, a також стратегічних та середньострокових загальнодержавних пріоритетних напрямів інноваційної діяльності;

- формування інноваційної культури та системи інноваційних цінностей у суб'єктів інноваційної діяльності для вироблення на їх основі нового типу креативного, інноваційного мислення та запровадження мотиваційних чинників до активної інноваційної діяльності;

- забезпечення підготовки спеціалістів i наукових кадрів вищої кваліфікації, перепідготовки та підвищення кваліфікації спеціалістів за перспективними науковотехнологічними напрямами, а також за напрямом спеціальностей «інноваційний менеджмент»; відродження творчої діяльності винахідників і раціоналізаторів виробництва.

У сфері інтелектуальної, зокрема, промислової власності:

- чітке та однозначне визначення об'єктів інтелектуальної власності

- відкриттів, винаходів, промислових зразків, ноу-хау, програмних продуктів та інших об'єктів, створених у сфері наукової та науково-технічної діяльності;

— визнання в якості суб'єктів інтелектуальної власності насамперед творчих осіб, які безпосередньо $\epsilon$ авторами об'єктів прав інтелектуальної власності, а також державу або підприємства, якщо вони фінансували проведення НДДКР, водночас не треба робити ці об'єкти виключно державною власністю, тому що держава не $\epsilon$ власником творчого дару особистості, а присвоєння державою інтелектуальної власності призведе до скорочення кількості винаходів та їх відтоку за кордон;

стимулювання економічної реалізації об'єктів прав інтелектуальної власності у вигляді інноваційного продукту через інноваційні процеси для отримання технологічної квазіренти, при цьому держава має налагодити оцінювання цих об'єктів і визначити правові рамки розподілу технологічної квазіренти від використання інноваційного продукту між його винахідником, виробником та державою;

- забезпечення ефективного захисту об'єктів прав інтелектуальної власності при введенні їх у господарський обіг через інноваційні процеси;

- запровадження обгрунтованого та економічно доцільного оцінювання об'єктів прав інтелектуальної власності як нематеріальних активів 3 відповідним підвищенням їх частки в структурі основного капіталу, особливо у промисловості;

— проведення інвентаризації та оцінювання 3 позицій прав інтелектуальної власності, технологічного рівня інноваційного потенціалу i його складових винахідницького, науковотехнічного, промислово-технологічного потенціалів за позиціями:

1) перспективні результати фундаментальних досліджень та прикладних НДДКР, технологій подвійного призначення, що перевищують сучасний досягнутий світовий рівень і можуть бути основою для радикальних інновацій, які визначають структуру п'ятого та шостого технологічних укладів;

2) результати НДДКР, винаходи, промислові технології, які можуть бути основою для поліпшуючих (інкрементальних) інновацій і мати впровадження в обмежених сегментах виробництва;

3) застарілі промислові технології, відзначені значною енерго-, ресурсовитратністю i техногенним навантаженням на довкілля та низькою продуктивністю для відмови від їх застосування i технічного переоснащення виробництв на передовій технологічні базі.

Державна підтримка має надаватися щодо введення у господарський обіг через інноваційні процеси об'єктів прав інтелектуальної власності кваліфікованим за першою позицією і тільки обмежена державна підтримка об'єктів інтелектуальної власності, віднесених до другої позиції для часткової інноваційної модернізації основних виробничих фондів.

У реальному секторі економіки та у сфері структурної політики: 
- підвищення рівня внутрішньої збалансованості національної еко-номіки для зменшення зовнішньої залежності розвитку іiі базових галузей за рахунок формування розвиненого, ємного внутрішнього ринку, системи власної міжгалузевої кооперації i раціонального забезпечення повних виробничих технологічних циклів;

- прискорення інноваційної реструктуризації виробництв за напрямами: їх інноваційного оновлення, адаптації до вимог конкурентного середовища, впровадження новітніх прогресивних технологій, зокрема, енерго-, ресурсозберігаючих технологій, зниження матеріало-місткості й енергоємності продукції, освоєння випуску конкуренто! спроможної інноваційної продукції разом 3 модернізацією суміжних виробництв, а також запровадження інноваційного менеджменту;

- подолання відставання та забезпечення прискореного розвитку сфери інформаційнокомунікаційних технологій та зв'язку, як ключового виробничого фактора п'ятого технологічного укладу економіки XXI століття;

- прискорення розвитку наукомістких галузей, а також окремих виробництв, що $\epsilon$ «точками зростання» прогресивного технологічного укладу або інноваційними лідерами за визначеними загальнодержавними, галузевими, регіональними інноваційними пріоритетами, що має забезпечити мультиплікаційне поширення технологічного впливу цих виробництв на інші суміжні виробництва та сфери діяльності;

- освоєння виробництва продукції, що забезпечує

інноваційної стратегічну незалежність держави від імпорту;

- створення гнучких багатофункціональних автоматизованих та робототехнічних виробничих систем, а також легко перенастроюваного модульного обладнання та технологій, що здатні до швидкої адаптації виробництва, до змін ринкового попиту на продукцію, це дозволить додержуватися високих темпів інноваційного оновлення продукції;

- забезпечення випереджаючого темпу розвитку машинобудівної, літакобудівної, суднобудівної, приладобудівної, електронної галузей, як найважливіших ланок промислового комплексу держави, що здатні забезпечити технологічний та інвестиційний прориви, а також створення на галузевому й регіональному рівнях обробних виробництв, які мають замкнуті технологічні цикли 3 виготовлення кінцевої інноваційної продукції з високою питомою вагою доданої вартості;
- здійснення інноваційного технологічного переоснащення виробництв базових галузей економіки для зменшення їх енерго-, ресурсовитратності, техногенного навантаження на довкілля та підвищення конкурентоздатності їх продукції;

- запровадження міжнародних систем якості, удосконалення систем стандартизації та метрології, зокрема, гармонізація національних стандартів із міжнародними;

- сприяння конверсії та диверсифікації надлишкових потужностей підприємств оборонно-промислового комплексу (ОПК), використання надбаного в ОПК науковотехнологічного потенціалу, зокрема, технологій «подвійного призначення» для прискорення розвитку наукомістких та високотехнологічних галузей і виробництв;

- у спеціальних (вільних) економічних зонах та на територіях пріоритетного розвитку, де встановлений спеціальний режим інвестиційної діяльності, запровадження стимулювання реалізації інноваційно-інвестиційних проектів, що передбачають трансфер новітніх технологій та освоєння випуску конкурентоспроможної продукції на зовнішньому ринку;

- розширення внутрішнього ринку високотехнологічної продукції, а також бази експорту наукомісткої продукції та продукції високого ступеня кінцевої обробки, організація державної підтримки виробництвам, що мають конкурентні переваги для своєї інноваційної продукції на світовому ринку;

- забезпечення розширеного інноваційного відтворення основних виробничих фондів на передовій технологічній базі;

Висновки i перспективи подалыших досліджень. Як підсумок необхідно підкреслити, що розвинуті економічно та технологічно країни світу перейшли до принципово нового типу розвитку економіки - інноваційного, характерними особливостями якого $\epsilon$ широкомасштабне впровадження у виробництво науково-технічних розробок та трансфер високопродуктивних технологій 3 метою їх комерціалізації, що стає причиною прогресивних технологічних змін реального сектора економіки, структури сфери споживання та підвищення конкурентоспроможності національної економіки у цілому. Визначальними факторами інноваційного розвитку економіки стають інтелектуальні ресурси такі як знання та кваліфікація людини, введені в господарський обіг інноваційних процесів об'єкти прав інтелектуальної власності, а також інвестиційні та інформаційні ресурси. 


\section{ПЕРЕЛІК ВИКОРИСТАНИХ ДЖЕРЕЛ}

1. Водачек Л. Реструктуризация - вызов чешским предприятиям / Л. Водачек // Проблемы теории и практики управления. - 1999. - № 1. - С. 84-89.

2. Бондар О.В. Інноваційна політика України в контексті сталого розвитку та Євроінтеграції / Інноваційна економіка // Всеукраїнський науково-виробничий журнал. - 2011. - 14 с.

3. Гусєв В. О. Державна інноваційна політика як фактор забезпечення національної безпеки України / В. О. Гусєв, Г. М. Довгаль // Актуальні проблеми державного управління : зб. наук. пр. Д. : ДРІДУ НАДУ, 2003. - Вип. 4 (14). - С. 108-124.

4. Гусєв В. О. Концептуальні засади формування державної інноваційної політики / В. О. Гусєв // Вісник Української Академії державного управління при Президентові України. — 2002. — № 4. C. 84-92.

5. Гусєв В. О. Імперативи і основні напрями інноваційної реструктуризації промислового комплексу України [Електронний ресурс] / В. О. Гусєв // Державне управління: теорія та практика. 2008. — № 1. - Режим доступу : http://www.nbuv.gov.ua/e-journals/ Dutp/2008-

1/txts/GALUZEVE/06gvosvo.pdf. — Заголовок з екрану.

6. Гусєв В. О. Інноваційна реструктуризація промислового комплексу України у форматі промислової інноваційної системи / В. О. Гусєв // Вісник НАДУ. - 2008. - № 3. - С. 81-93.

7. Гусєв В. О. Мета, принципи та стратегії державної інноваційної політики / В. О. Гусєв // Актуальні проблеми державного управління : зб. наук. праць. - Одеса : ОРІДУ УАДУ, 2002. — Вип. 12. - C. 16-27.

8. Гусєв В. О. Система пріоритетів державної інноваційної політики / В. О. Гусєв // Збірник наукових праць Української Академії державного управління при Президентові України. — К., 2002. — Вип. 2. - С. 100-107.

9. Закон України «Про основи національної безпеки України» від 19 червня 2003 р. № 964.

10. Красноутська Н.В. Інноваційний менеджмент /Красноутська Н.В. // Навч. посібник. - К.: KHEУ, 2003. - $136 \mathrm{c}$.

11. Миротин Л. Б. Логистическое администрирование : учебное пособие / Л. Б. Миротин, А. Б. Чубуков, И. Э. Ташбаев. - М. : Экзамен, 2003. — 480 с.

12. Реструктуризация предприятий и компаний : справочное пособие / И. И. Мазур, В. Д. Шапиро и др. ; под ред. И. И. Мазура. - М. : Высшая школа, 2000. - 587 с.

\section{REFERENCES}

1. Vodachek, L. (1999). Restrukturyzatsiya — vyzov cheshskym predpriyatiyam [Restructuring as a challenge to Czech enterprises]. Problemy teorii i praktiki upravleniya - Problems of management theory and practice, 1, 84-89 [in Russian].

2. Bondar, O.V. (2011). Innovaciyna polityka Ukrainy v konteksti stalogo rozvytku ta Yevrointegracii [Innovation policy of ukraine in the context of stable development and integration]. Innovaciyna ekonomika Innovation Economy [in Ukrainian].

3. Gusev, V. O. (2003). Derzhavna innovaciyna polityka yak faktor zabezpechennya nacional noi bezpeky Ukrainy [State innovation policy as a factor in the protection of national security of Ukraine]. Aktual'ni problemy derzhavnogo upravlinnya - Actual problems of public administration, 4 (14), 108-124 [in Ukrainian].

4. Gusev, V. O. (2002). Konceptual ni zasady formuvannya derzhavnoi innovacinoi polityky [Conceptual foundations of state innovation policy formation]. Visnyk Ukrains `koi Akademii derzhavnogo upravlinnya pry Prezydentovi Ukrainy - Bulletin of the Ukrainian Academy of Public Administration under the President of Ukraine, 4, 84-92 [in Ukrainian].

5. Gusev, V. O. (2008). Imperatyvy i osnovni napryamy innovaciynoi restrukturyzacii promyslovogo kompleksu Ukrainy [Imperatives and main directions of innovative restructuring of the industrial complex of Ukraine]. Derzhavne upravlinnya: teoriya ta praktyka - Public administration: theory and practice, 1. nbuv.gov.ua. Retrieved from: Rezhym dostupu : http://www.nbuv.gov.ua/e-journals/ Dutp/20081/txts/GALUZEVE/06gvosvo.pdf. [in Ukrainian].

6. Gusev, V. O. (2008). Innovaciyna restrukturyzaciya promyslovogo kompleksu Ukrainy u formati promyslovoi innovaciynoi systemy [Innovative restructuring of the industrial complex of Ukraine in the format of the industrial innovation system]. Visnyk NADU - Bulletin of NADU, 3, 81-93 [in Ukrainian]. 
7. Gusev, V. O. (2002). Meta, pryncypy ta strategii derzhavnoi innovaciyanoi polityky [The purpose, principles and strategies of the state innovation policy]. Aktual'ni problemy derzhavnogo upravlinnya Actual problems of public administration, 12, 16-27 [in Ukrainian].

8. Gusev, V. O. (2002). Systema priorytetiv derzhavnoi innovacinoi polityky [System of priorities of state innovation policy]. Zbirnyk naukovykh prac' Ukrains`koi Akademii derzhavnogo upravlinnya pry Prezydentovi Ukrainy - Bulletin of the Ukrainian Academy of Public Administration under the President of Ukraine, 2, 100-107 [in Ukrainian].

9. Zakon Ukrainy «Pro osnovy nacional`noi bezpeky Ukrainy» № 964 vid 19 chervnya 2003 r. [Law of Ukraine «On the basics of national security of Ukraine» № 964 from June 19, 2003]. (June 19, 2003).[in Ukrainian].

10. Krasnoutska, N.V. (2003). Innovaciynyi menedzhment [Innovative management]. K.: KNEU [in Ukrainian].

11. Mirotin, L. B. (2003). Logisticheskoe administrirovanie: uchebnoe posobie [Logistics administration: a textbook]. M. : Ekzamen [in Russian].

12. Mazur I. I. (Ed.) (2000). Restrukturizaciya predpriyatiy i kompaniy: spravochnoe posobie [Restructuring of enterprises and companies: a reference manual]. M. : Vysshaya shkola, [in Russian].

Отримано 30.08.2019 